\title{
Micromonospora pattaloongensis sp. nov., isolated from a Thai mangrove forest
}

Correspondence

Chitti Thawai

ktchitti@kmitl.ac.th
Chitti Thawai, ${ }^{1}$ Somboon Tanasupawat ${ }^{2}$ and Takuji Kudo ${ }^{3}$

\author{
${ }^{1}$ Department of Applied Biology, Faculty of Science, King Mongkut's Institute of Technology \\ Ladkrabang, Bangkok 10520, Thailand \\ ${ }^{2}$ Department of Microbiology, Faculty of Pharmaceutical Sciences, Chulalongkorn University, \\ Bangkok 10330, Thailand \\ ${ }^{3}$ Japan Collection of Microorganisms, RIKEN BioResource Center, Wako, Saitama 351-0198, \\ Japan
}

\begin{abstract}
An actinomycete, designated strain $\mathrm{TJ} 2-2^{\top}$, was isolated from soil collected from a mangrove forest in Pattaloong Province, Thailand, and was subjected to morphological and chemotaxonomic analysis and phylogenetic investigation based on 16S rRNA gene sequences. The data from these analyses indicated that the novel strain should be classified as a member of the genus Micromonospora and that the closest relative was Micromonospora olivasterospora DSM $43868^{\top}$ ( $98.7 \%$ gene sequence similarity). The DNA-DNA hybridization data and some physiological and biochemical properties indicated that the novel strain could be readily distinguished from its closest phylogenetic relatives. On the basis of these phenotypic and genotypic data, strain TJ2-2 ${ }^{\top}$ represents a novel species of the genus Micromonospora, for which the name Micromonospora pattaloongensis sp. nov. is proposed. The type strain is $\mathrm{TJ} 2-2^{\top}(=\mathrm{JCM}$ $12833^{\top}=$ TISTR $1559^{\top}$ ).
\end{abstract}

The genus Micromonospora Ørskov (1923) belongs to the family Micromonosporaceae in the order Actinomycetales (Stackebrandt et al., 1997). This genus is well established in terms of morphological and chemotaxonomic properties (Lechevalier \& Lechevalier, 1970; Lechevalier et al., 1977; Kroppenstedt, 1985) as well as 16S rRNA gene sequencebased phylogeny (Stackebrandt et al., 1997). In 2006, a novel genus in the family Micromonosporaceae was proposed, Polymorphospora, with the description of Polymorphospora rubra (Tamura et al., 2006). This genus is very similar to the genus Micromonospora but differs in some morphological and chemotaxonomic characteristics.

As mangrove environments differ greatly from terrestrial habitats, the distribution and biological characteristics of mangrove actinomycetes are expected to be different from those of soil actinomycetes. Studies on the biodiversity of mangrove actinomycetes are important not only in terms of basic research, but also for the biotechnological exploitation of such organisms.

During an investigation of novel actinomycetes from soil collected in a mangrove forest in southern Thailand, we isolated a strain, designated $\mathrm{TJ} 2-2^{\mathrm{T}}$, showing morphological and chemotaxonomic characteristics typical of

Abbreviation: $\mathrm{A}_{2} \mathrm{pm}$, diaminopimelic acid.

The GenBank/EMBL/DDBJ accession number for the $16 \mathrm{~S}$ rRNA gene sequence of strain TJ2-2 ${ }^{\top}$ is AB275607. members of the genus Micromonospora but which was genotypically and phenotypically distinguishable from all recognized Micromonospora species. Here, we describe the polyphasic characterization of strain $\mathrm{TJ} 2-2^{\mathrm{T}}$ and describe it as a novel species of the genus Micromonospora.

Strain TJ2-2 $2^{\mathrm{T}}$ was isolated from a soil sample collected from a mangrove forest in Pattaloong Province, Thailand. The sample was taken from the soil surface and kept at $4{ }^{\circ} \mathrm{C}$. The sampling and isolation methods were as described by Thawai et al. (2004); the purified culture was maintained at $4-10{ }^{\circ} \mathrm{C}$ on yeast extract-malt extract (ISP 2) agar slants.

Morphological properties of this strain grown on ISP 2 agar medium were observed by using light microscopy and scanning electron microscopy (JSM-5410 LV; JEOL). The sample used for scanning electron microscopy was prepared as described previously (Itoh et al., 1989).

Phenotypic characteristics were examined by using several standard methods; cultural characteristics were tested using 14 day cultures grown at $30{ }^{\circ} \mathrm{C}$ on various agar media. The Jacal Colour Card L2200 (Japan Colour Research Institute) was used for determining colour designations. The decomposition of various compounds was examined using the basal medium recommended by Gordon et al. (1974). The temperature, $\mathrm{pH}$ and $\mathrm{NaCl}$ tolerances were determined on ISP 2 medium. Carbon-source utilization was tested by using 


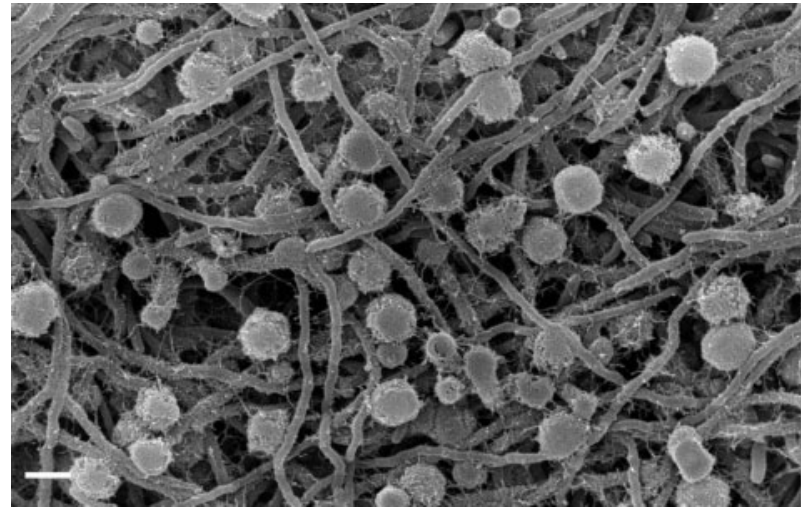

Fig. 1. Scanning electron micrograph of cells of strain $T J 2-2^{\top}$ grown on humic acid-vitamin agar for 4 weeks at $28^{\circ} \mathrm{C}$. Bar, $1 \mu \mathrm{m}$.

ISP 9 medium (Shirling \& Gottlieb, 1966) supplemented with $1 \%$ (final concentration) carbon source and $0.05 \%$ Casamino acids. Gelatin liquefaction, milk peptonization, nitrate reduction and starch hydrolysis were determined through cultivation on various media as described by Arai (1975) and Williams \& Cross (1971). Melanin and hydrogen sulfide production were investigated on slants of tyrosine agar (ISP 7) and peptone iron agar (ISP 6), respectively, supplemented with $0.1 \%(\mathrm{w} / \mathrm{v})$ yeast extract.

Freeze-dried cells used for chemotaxonomic analyses were obtained from cultures grown in ISP 2 broth on a rotary shaker at $30{ }^{\circ} \mathrm{C}$ for 4 days. Cell-wall peptidoglycan was prepared and hydrolysed by following the methods of Kawamoto et al. (1981); the amino acid composition was analysed with an automatic amino acid analyser (L-8500A, Hitachi). The isomers of diaminopimelic acid $\left(\mathrm{A}_{2} \mathrm{pm}\right)$ present in the cell walls were determined according to the method of Staneck \& Roberts (1974). The acyl group of the muramic acid in the peptidoglycan was determined by the method of Uchida \& Aida (1984). The reducing sugars from whole-cell hydrolysates were analysed by using HPLC according to Mikami \& Ishida (1983). Phospholipids in the cells were extracted and analysed as described by Minnikin et al. (1984). Fatty acid methyl ester analysis was performed by using GLC according to the instructions of the Microbial Identification System (MIDI) (Sasser, 1990; Kämpfer \& Kroppenstedt, 1996). Isoprenoid quinones were extracted according to Collins et al. (1977) and were analysed by using HPLC with a Cosmosil $5 \mathrm{C}_{18}$ column $(4.6 \times 150 \mathrm{~mm}$; Nacalai Tesque). The elution solvent was a mixture of methanol and 2-propanol $(2: 1, \mathrm{v} / \mathrm{v})$.

Chromosomal DNA was isolated from cells grown in ISP 2 broth according to the method of Tamaoka (1994). The $\mathrm{G}+\mathrm{C}$ content of the DNA was determined by HPLC as described by Tamaoka \& Komagata (1984). An equimolar mixture of nucleotides (Yamasa Shoyu) was used as the quantitative standard. DNA-DNA relatedness was measured fluorometrically using the microplate hybridization method devised by Ezaki et al. (1989). Hybridization was carried out at $55{ }^{\circ} \mathrm{C}$ for $2 \mathrm{~h}$.

Genomic DNA extraction, PCR-mediated amplification of the 16S rRNA gene and sequencing of the PCR products were carried out as described previously (Nakajima et al., 1999). The 16S rRNA gene sequence was multiply aligned with selected sequences obtained from the GenBank/ EMBL/DDBJ databases by using CLUSTAL w, version 1.81 (Thompson et al., 1994). The alignment was manually verified and adjusted prior to the construction of a phylogenetic tree. The phylogenetic tree was constructed by using the neighbour-joining (Saitou \& Nei, 1987) and maximum-parsimony methods (Kluge \& Farris, 1969) in MEGA, version 2.1 (Kumar et al., 2001). The confidence values for the branches of the phylogenetic tree were determined using bootstrap analyses (Felsenstein, 1985) based on 1000 resamplings. The values for sequence

Table 1. Cellular fatty acid contents (\%) of strain $T J 2-2^{\top}$ and M. olivasterospora JCM $7348^{\top}$

\begin{tabular}{|c|c|c|}
\hline Fatty acid & Strain $\mathrm{TJ} 2-2^{\mathrm{T}}$ & $\begin{array}{l}\text { M. olivasterospora } \\
\text { JCM } 7348^{\mathrm{T}}\end{array}$ \\
\hline \multicolumn{3}{|l|}{ Saturated fatty acids } \\
\hline $\mathrm{C}_{14: 0}$ & 0.3 & 0.3 \\
\hline $\mathrm{C}_{15: 0}$ & 2.2 & 0.4 \\
\hline $\mathrm{C}_{16: 0}$ & 0.7 & 1.9 \\
\hline $\mathrm{C}_{17: 0}$ & 0.5 & 0.8 \\
\hline $\mathrm{C}_{18: 0}$ & 0.3 & 1.9 \\
\hline 10-Methyl $C_{16: 0}$ & - & 3.0 \\
\hline 10-Methyl $\mathrm{C}_{17: 0}$ & 2.6 & 0.9 \\
\hline TBSA 10-methyl $C_{18: 0}$ & 0.1 & 1.3 \\
\hline \multicolumn{3}{|l|}{ Unsaturated fatty acids } \\
\hline $\mathrm{C}_{15: 1} \omega 6 c$ & 1.0 & - \\
\hline $\mathrm{C}_{16: 1} 2-\mathrm{OH}$ & - & 1.0 \\
\hline $\mathrm{C}_{17: 1} \omega 6 c$ & 0.2 & - \\
\hline $\mathrm{C}_{17: 1} \omega 8 c$ & 11.3 & 1.0 \\
\hline iso- $\mathrm{C}_{17: 1} \omega 9 c$ & 6.5 & - \\
\hline anteiso- $\mathrm{C}_{17: 1} \omega 9 c$ & 3.8 & 0.6 \\
\hline $\mathrm{C}_{18: 1} \omega 5 c$ & - & 1.3 \\
\hline $\mathrm{C}_{18: 1} \omega 7 c$ & 0.3 & - \\
\hline $\mathrm{C}_{18: 1} \omega 9 c$ & 3.0 & 0.7 \\
\hline \multicolumn{3}{|l|}{ Branched fatty acids } \\
\hline iso- $\mathrm{C}_{13: 0}$ & 0.1 & 0.1 \\
\hline iso- $\mathrm{C}_{14: 0}$ & 6.1 & 4.0 \\
\hline iso- $\mathrm{C}_{15: 0}$ & 24.4 & 20.2 \\
\hline anteiso- $\mathrm{C}_{15: 0}$ & 10.0 & 6.5 \\
\hline iso- $\mathrm{C}_{16: 0}$ & 38.9 & 36.0 \\
\hline iso- $\mathrm{C}_{16: 1}$ & 9.7 & 1.3 \\
\hline iso- $\mathrm{C}_{17: 0}$ & 3.2 & 6.4 \\
\hline iso- $\mathrm{C}_{17: 0} 3-\mathrm{OH}$ & - & 0.4 \\
\hline anteiso- $\mathrm{C}_{17: 0}$ & 9.6 & 7.6 \\
\hline anteiso- $\mathrm{C}_{17: 1}$ & - & 0.6 \\
\hline iso- $\mathrm{C}_{18: 0}$ & 0.4 & 1.0 \\
\hline iso- $\mathrm{C}_{18: 1}$ & 0.4 & - \\
\hline
\end{tabular}




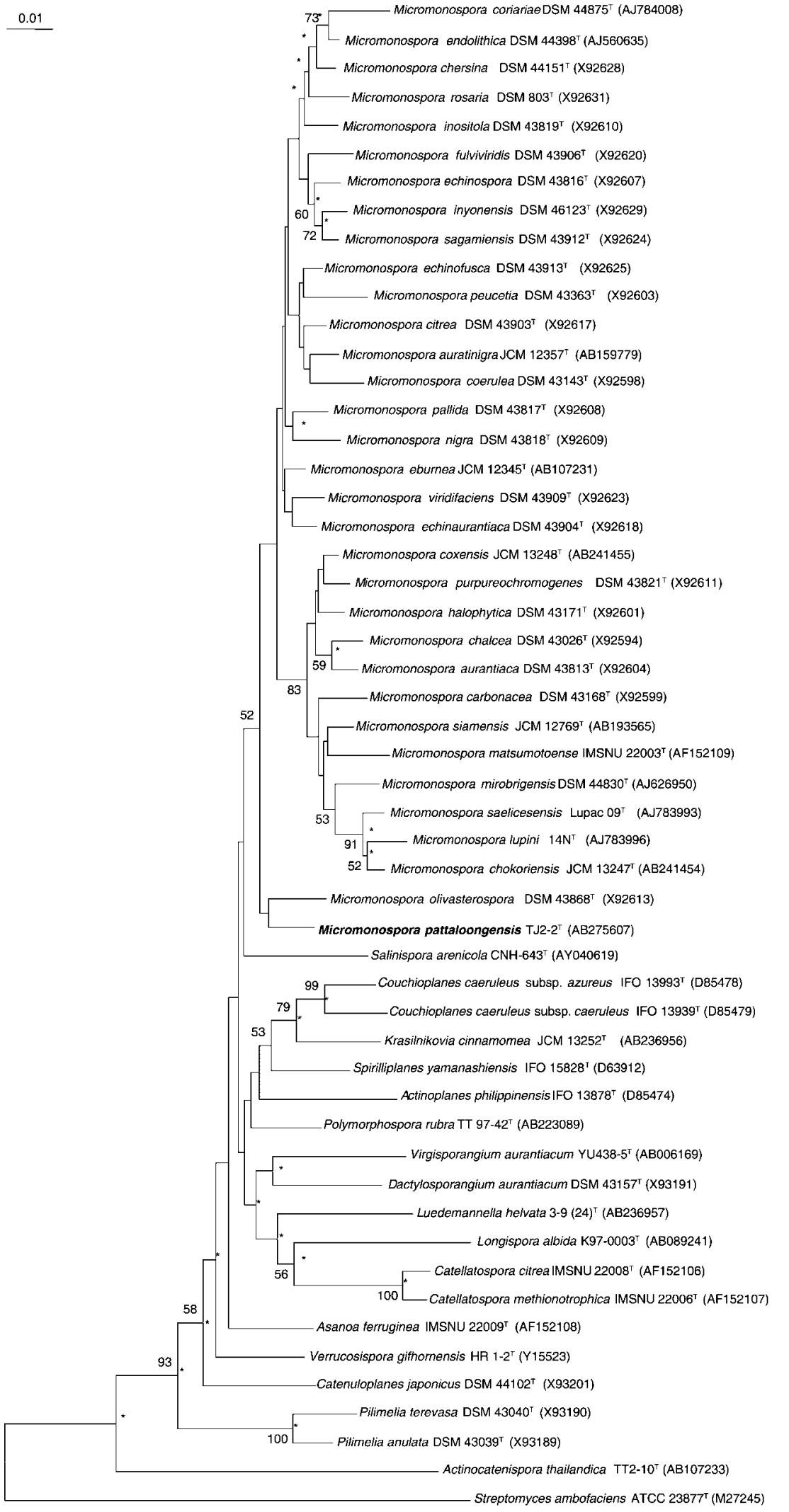

Fig. 2. Neighbour-joining phylogenetic tree (Saitou \& Nei, 1987), based on almostcomplete 16S rRNA gene sequences, showing the relationships between strain $\mathrm{TJ}_{2}-2^{\top}$, recognized species of the genus Micromonospora and members of the family Micromonosporaceae. Streptomyces ambofaciens ATCC $23877^{\top}$ was used as an outgroup. Asterisks indicate branches that were also found using the maximum-parsimony (Kluge \& Farris, 1969) method. Numbers at branch points indicate bootstrap percentages (based on 1000 replicates); only values $>50 \%$ are indicated. Bar, 0.01 substitutions per nucleotide position.

similarity among the closest strains were calculated manually after obtaining pairwise alignments using
CLUSTAL_X (Thompson et al., 1997). Gaps and ambiguous nucleotides were eliminated from the calculations. 
The morphological and chemical properties of strain $\mathrm{T} / 2-2^{\mathrm{T}}$ were consistent with its classification as a member of the genus Micromonospora (Kawamoto, 1989). The growth of strain $\mathrm{TJ} 2-2^{\mathrm{T}}$ was good on ISP 2, oatmeal agar (ISP 3), peptone-yeast extract-iron agar (ISP 6) and nutrient agar (BD, Difco). Colonies on these media were raised and folded; well-developed, branched substrate hyphae were produced but aerial hyphae were not present. Single, non-motile, spherical spores $(0.6-0.9 \mu \mathrm{m})$ were observed; the spore surface was warty (Fig. 1). The colour of the sporulating colonies was yellowish white to pale orange. A yellow, soluble pigment was produced in ISP 2, ISP 3 and nutrient agar. The cell-wall hydrolysates contained glutamic acid, glycine, alanine and $\mathrm{A}_{2} \mathrm{pm}$; the $\mathrm{A}_{2} \mathrm{pm}$ isomer was meso, indicating that this strain has wall chemotype II (Lechevalier \& Lechevalier, 1970) and peptidoglycan type Al $\gamma$ (Schleifer \& Kandler, 1972). The acyl type of the cell-wall muramic acid was glycolyl. Glucose, xylose, arabinose, galactose, mannose and ribose were found as whole-cell sugars, but rhamnose was not detected (whole-cell sugar pattern D; Lechevalier \& Lechevalier, 1970). The characteristic phospholipids were diphosphatidylglycerol, phosphatidylinositol, phosphatidylinositol mannosides and phosphatidylethanolamine, whereas phosphatidylcholine was not present: this pattern corresponds to phospholipid type PII (Lechevalier et al., 1977). The major cellular fatty acids of this strain were iso$\mathrm{C}_{16: 0}$, iso- $\mathrm{C}_{15: 0}, \mathrm{C}_{17: 1} \omega 8 c$, anteiso- $\mathrm{C}_{15: 0}$ and anteiso- $\mathrm{C}_{17: 0}$; 10-methyl $\mathrm{C}_{17: 0}$ was also present. This pattern corresponds to fatty acid type 3b (Kroppenstedt, 1985) (Table 1). Mycolic acids were absent. The predominant menaquinones were MK-10 $\left(\mathrm{H}_{4}\right) \quad(56.1 \%), \quad M K-10\left(\mathrm{H}_{6}\right)(22.8 \%), \quad M K-10\left(\mathrm{H}_{8}\right)$ $(8.6 \%)$; small amounts of MK-9 $\left(\mathrm{H}_{4}\right)(4.7 \%)$, MK-9 $\left(\mathrm{H}_{6}\right)$ $(1.6 \%)$ and MK-9 $\left(\mathrm{H}_{2}\right)(0.4 \%)$ were also present. The $\mathrm{G}+\mathrm{C}$ content of the DNA was $71.5 \mathrm{~mol} \%$.

The 16S RNA gene sequence analysis of strain TJ2-2 $2^{\mathrm{T}}(1511$ nucleotides) showed that it exhibited a close relationship with members of the family Micromonosporaceae, being located within the clade of the genus Micromonospora (Fig. 2). Comparison of the 16S RNA gene sequence of strain $\mathrm{TJ} 2-2^{\mathrm{T}}$ with corresponding sequences from the type strains of recognized species of the genus Micromonospora and from members of the family Micromonosporaceae indicated that this strain was closely related to the type strains of Micromonospora olivasterospora (Kawamoto et al., 1983) and Polymorphospora rubra (Tamura et al., 2006), the highest level of sequence similarity being $98.7 \%$. The signature nucleotide positions of strain $\mathrm{TJ} 2-2^{\mathrm{T}}$ were compared with those of its closest relatives (Table 2).

The characteristics shown in Table 3 clearly indicate that strain $\mathrm{TJ} 2-2^{\mathrm{T}}$ possesses some distinct phenotypic and chemotaxonomic profiles that distinguish it from its closest phylogenetic relative, M. olivasterospora JCM $7348^{\mathrm{T}}$, and members of the genus Polymorphospora. In particular, the following features serve to distinguish strain $\mathrm{TJ} 2-2^{\mathrm{T}}$ from related micro-organisms: the colour of sporulating colonies, the presence/absence of aerial mycelium, the presence/
Table 2. Comparison of $16 \mathrm{~S}$ rRNA gene signature nucleotide positions of strain $\mathrm{TJ} 2-2^{\top}$ and the most closely related genera

The nucleotide positions of bases or base pairs are given according to Escherichia coli numbering (Brosius et al., 1978). The data for the genus Micromonospora are taken from Ara \& Kudo (2007).

\begin{tabular}{|c|c|c|c|}
\hline Position & Strain $\mathrm{TJ} 2-2^{\mathrm{T}}$ & Micromonospora & Polymorphospora \\
\hline 129 & $\mathrm{U}$ & $\mathrm{C}$ & $\mathrm{U}$ \\
\hline $139-224$ & $\mathrm{~A}-\mathrm{U}$ & $\mathrm{A}-\mathrm{U}$ & $\mathrm{A}-\mathrm{U}$ \\
\hline $140-223$ & $\mathrm{G}-\mathrm{C}$ & $\mathrm{G}-\mathrm{U}$ & $\mathrm{G}-\mathrm{U}$ \\
\hline $144-178$ & $\mathrm{U}-\mathrm{G}$ & $\mathrm{U}-\mathrm{A}$ & $\mathrm{U}-\mathrm{G}$ \\
\hline 222 & $\mathrm{C}$ & $\mathrm{C}$ & $\mathrm{C}$ \\
\hline 232 & G & G & G \\
\hline 262 & G & G & G \\
\hline 381 & G & G & G \\
\hline 415 & $\mathrm{C}$ & $\mathrm{C}$ & $\mathrm{C}$ \\
\hline 456 & $\mathrm{U}$ & $\mathrm{U}$ & $\mathrm{C}$ \\
\hline 546 & G & G & G \\
\hline $594-645$ & $\mathrm{C}-\mathrm{G}$ & $\mathrm{C}-\mathrm{G}$ & $\mathrm{C}-\mathrm{G}$ \\
\hline $602-636$ & $\mathrm{C}-\mathrm{G}$ & $\mathrm{C}-\mathrm{G}$ & $\mathrm{C}-\mathrm{G}$ \\
\hline $616-624$ & $\mathrm{G}-\mathrm{C}$ & $\mathrm{G}-\mathrm{C}$ & $\mathrm{A}-\mathrm{U}$ \\
\hline $615-625$ & $\mathrm{C}-\mathrm{G}$ & $\mathrm{C}-\mathrm{G}$ & $\mathrm{C}-\mathrm{G}$ \\
\hline $656-750$ & $\mathrm{G}-\mathrm{C}$ & $\mathrm{G}-\mathrm{C}$ & $\mathrm{G}-\mathrm{C}$ \\
\hline $836-850$ & $\mathrm{G}-\mathrm{C}$ & $\mathrm{G}-\mathrm{C}$ & $\mathrm{G}-\mathrm{C}$ \\
\hline 859 & $\mathrm{C}$ & $\mathrm{C}$ & $\mathrm{C}$ \\
\hline 968 & $\mathrm{~A}$ & A & A \\
\hline $998-1043$ & $\mathrm{G}-\mathrm{C}$ & $\mathrm{G}-\mathrm{C}$ & $\mathrm{G}-\mathrm{C}$ \\
\hline 1003 & A & $\mathrm{A}$ & A \\
\hline 1006 & $\mathrm{U}$ & A & $\mathrm{U}$ \\
\hline 1010 & G & G & G \\
\hline $1011-1018$ & $\mathrm{C}-\mathrm{G}$ & $\mathrm{C}-\mathrm{G}$ & $\mathrm{C}-\mathrm{G}$ \\
\hline $1012-1017$ & $\mathrm{~A}-\mathrm{U}$ & $\mathrm{A}-\mathrm{U}$ & $\mathrm{A}-\mathrm{U}$ \\
\hline $1119-1154$ & $\mathrm{U}-\mathrm{A}$ & $\mathrm{U}-\mathrm{A}$ & $\mathrm{U}-\mathrm{A}$ \\
\hline $1121-1152$ & $\mathrm{G}-\mathrm{C}$ & $\mathrm{G}-\mathrm{C}$ & $\mathrm{G}-\mathrm{C}$ \\
\hline 1252 & $\mathrm{U}$ & $\mathrm{U}$ & $\mathrm{U}$ \\
\hline $1445-1457$ & $\mathrm{C}-\mathrm{G}$ & $\mathrm{C}-\mathrm{G}$ & U-G \\
\hline
\end{tabular}

absence of spore chains, the major whole-organism sugars, the fatty acid profile, the type of $\mathrm{A}_{2} \mathrm{pm}$ in the cell wall, the liquefaction of gelatin and the utilization profile for melibiose, raffinose, L-rhamnose, D-ribose and salicin. Furthermore, a low level of DNA-DNA relatedness (16.8\%) was observed between strain TJ2-2 ${ }^{\mathrm{T}}$ and M. olivasterospora JCM $7348^{\mathrm{T}}$.

It is evident from the genotypic and phenotypic data presented above that strain $\mathrm{TJ} 2-2^{\mathrm{T}}$ is distinguishable from previously described Micromonospora species and members of the most closely related genus, Polymorphospora. Therefore strain $\mathrm{TJ} 2-2^{\mathrm{T}}$ represents a novel species of the genus Micromonospora, for which the name Micromonospora pattaloongensis sp. nov. is proposed.

\section{Description of Micromonospora pattaloongensis sp. nov.}

Micromonospora pattaloongensis (pat.ta.loong.en'sis. N.L. fem. adj. pattaloongensis pertaining to Pattaloong, where the type strain was isolated). 
Table 3. Differential characteristics of strain $\mathrm{TJ} 2-2^{\top}$ and its closest relatives

Strains: 1 , TJ2-2 $2^{\mathrm{T}}$; 2, M. olivasterospora JCM $7348^{\mathrm{T}}$; 3, P. rubra TT 97-42 ${ }^{\mathrm{T}}$ (data from Tamura et al., 2006). +, Positive; -, negative; ND, not determined.

\begin{tabular}{|c|c|c|c|}
\hline Characteristic & 1 & 2 & 3 \\
\hline Colony colour on ISP 2 medium & Yellowish white & Greenish black & Red to reddish orange \\
\hline Aerial mycelium & - & - & + \\
\hline Spore chains & - & - & + \\
\hline Cell-wall $\mathrm{A}_{2} \mathrm{pm}$ & meso- $\mathrm{A}_{2} \mathrm{pm}$ & $3-\mathrm{OH}-m e s o-\mathrm{A}_{2} \mathrm{pm}$ & meso- $\mathrm{A}_{2} \mathrm{pm}$ \\
\hline Major whole-organism sugars & Xylose, arabinose & Xylose, arabinose & Xylose \\
\hline Fatty acid type & $3 b$ & $3 \mathrm{~b}$ & $2 \mathrm{a}$ \\
\hline Major menaquinones (\%) & $\begin{array}{l}\mathrm{MK}-10\left(\mathrm{H}_{4}\right)(56.1), \\
\mathrm{MK}-10\left(\mathrm{H}_{6}\right)(22.8)\end{array}$ & $\begin{array}{c}\text { MK-10 }\left(\mathrm{H}_{4}\right)(31.7), \\
\left.\text { MK-10( } \mathrm{H}_{6}\right)\end{array}$ & $\begin{array}{l}\text { MK-10 }\left(\mathrm{H}_{6}\right)(34-35), \\
\left.\text { MK-10( } \mathrm{H}_{4}\right)(20-28)\end{array}$ \\
\hline DNA G $+C$ content $(\mathrm{mol} \%)$ & 71.5 & 71.9 & 70.2 \\
\hline Gelatin liquefaction & + & - & ND \\
\hline \multicolumn{4}{|l|}{ Utilization of: } \\
\hline Melibiose & - & + & + \\
\hline Raffinose & - & + & + \\
\hline D-Ribose & + & - & ND \\
\hline L-Rhamnose & - & + & + \\
\hline Salicin & + & - & $\mathrm{ND}$ \\
\hline
\end{tabular}

Gram-positive, mesophilic, non-motile actinomycete that forms well-developed and branched substrate hyphae. Colonies are yellowish white to pale orange in ISP 2 medium. Single spores are formed on substrate hyphae. Aerial mycelium is absent. The spore surface appears warty. Spores are non-motile. A yellow soluble pigment is produced in ISP 2, ISP 3 and nutrient agar. Nitrate is reduced to nitrite. Utilizes L-arabinose, D-fructose, Dgalactose, D-glucose, lactose, D-ribose, salicin and Dxylose; shows weak utilization of cellobiose, but does not utilize glycerol, D-mannitol, melibiose, raffinose or Lrhamnose. Positive for milk peptonization, starch hydrolysis and gelatin liquefaction, but negative for melanin formation and $\mathrm{H}_{2} \mathrm{~S}$ production. The optimal temperature for growth is $25-30{ }^{\circ} \mathrm{C}$; no growth occurs above $40{ }^{\circ} \mathrm{C}$. The maximum $\mathrm{NaCl}$ concentration for growth is $3 \%$. The cell wall contains glutamic acid, glycine, alanine and meso- $\mathrm{A}_{2} \mathrm{pm}$ in the molar ratio $1: 0.9: 0.5: 1.1$. The acyl type of the cell-wall muramic acid is glycolyl. The predominant menaquinone is $\mathrm{MK}-10\left(\mathrm{H}_{4}\right)$. The characteristic whole-cell sugars are xylose and arabinose. The phospholipid profile comprises diphosphatidylglycerol, phosphatidylinositol mannosides, phosphatidylinositol and phosphatidylethanolamine; phosphatidylcholine is not present. The major fatty acids of the type strain are iso- $\mathrm{C}_{16: 0}(38.9 \%)$, iso- $\mathrm{C}_{15: 0}(24.4 \%), \mathrm{C}_{17: 1} \omega 8 c(11.3 \%)$, anteiso- $\mathrm{C}_{15: 0}(10.0 \%)$, iso- $\mathrm{C}_{16: 1}(9.7 \%)$, anteiso- $\mathrm{C}_{17: 0}$ $(9.6 \%)$ and 10-methyl $\mathrm{C}_{17: 0}(2.6 \%)$. The DNA G+C content is $71.5 \mathrm{~mol} \%$.

The type strain, TJ2-2 ${ }^{\mathrm{T}}\left(=\mathrm{JCM} 12833^{\mathrm{T}}=\mathrm{TISTR} 1559^{\mathrm{T}}\right)$, was isolated from a soil sample collected from a mangrove forest in Pattaloong Province, Thailand.

\section{Acknowledgements}

A research grant from the Thailand Research Fund and the Commission on Higher Education, Ministry of Education, Thailand (to C. T.) is gratefully acknowledged. We thank M. Chijimatsu and H. Morishita of the Research Resources Center, RIKEN Brain Science Institute, for analysing the amino acid composition of the cell-wall peptidoglycan.

\section{References}

Ara, I. \& Kudo, T. (2007). Luedemannella gen. nov., a new member of the family Micromonosporaceae and description of Luedemannella helvata sp. nov. and Luedemannella flava sp. nov. J Gen Appl Microbiol 53, 39-51.

Arai, T. (1975). Culture Media for Actinomycetes. Tokyo: The Society for Actinomycetes Japan.

Brosius, J., Palmer, J. L., Kennedy, J. P. \& Noller, H. F. (1978). Complete nucleotide sequence of a $16 \mathrm{~S}$ ribosomal RNA gene from Escherichia coli. Proc Natl Acad Sci U S A 75, 4801-4805.

Collins, M. D., Pirouz, T., Goodfellow, M. \& Minnikin, D. E. (1977). Distribution of menaquinones in actinomycetes and corynebacteria. $J$ Gen Microbiol 100, 221-230.

Ezaki, T., Hashimoto, Y. \& Yabuuchi, E. (1989). Fluorometric deoxyribonucleic acid-deoxyribonucleic acid hybridization in microdilution wells as an alternative to membrane filter hybridization in which radioisotopes are used to determine genetic relatedness among bacterial strains. Int J Syst Bacteriol 39, 224-229.

Felsenstein, J. (1985). Confidence limits on phylogenies: an approach using the bootstrap. Evolution 39, 783-791.

Gordon, R. E., Barnett, D. A., Handerhan, J. E. \& Pang, C. H.-N. (1974). Nocardia coeliaca, Nocardia autotrophica, and the nocardin strain. Int J Syst Bacteriol 24, 54-63.

Itoh, T., Kudo, T., Parenti, F. \& Seino, A. (1989). Amended description of the genus Kineosporia, based on chemotaxonomic and morphological studies. Int J Syst Bacteriol 39, 168-173. 
Kämpfer, P. \& Kroppenstedt, R. M. (1996). Numerical analysis of fatty acid patterns of coryneform bacteria and related taxa. Can J Microbiol 42, 989-1005.

Kawamoto, I. (1989). Genus Micromonospora. In Bergey's Manual of Systematic Bacteriology, vol. 4, pp. 2442-2450. Edited by S. T. Williams, M. E. Sharpe \& J. G. Holt. Baltimore: Williams \& Wilkins.

Kawamoto, I., Oka, T. \& Nara, T. (1981). Cell wall composition of Micromonospora olivoasterospora, Micromonospora sagamiensis, and related organisms. J Bacteriol 146, 527-534.

Kawamoto, I., Yamamoto, M. \& Nara, T. (1983). Micromonospora olivasterospora sp. nov. Int J Syst Bacteriol 33, 107-112.

Kluge, A. G. \& Farris, F. S. (1969). Quantitative phyletics and the evolution of anurans. Syst Zool 18, 1-32.

Kroppenstedt, R. M. (1985). Fatty acid and menaquinone analysis of actinomycetes and related organisms. In Chemical Methods in Bacterial Systematics, pp. 173-199. Edited by M. Goodfellow \& D. E. Minnikin. London: Academic Press.

Kumar, S., Tamura, K., Jakobsen, I. B. \& Nei, M. (2001). MEGA2: molecular evolutionary genetics analysis software. Bioinformatics 17, 1244-1245.

Lechevalier, M. P. \& Lechevalier, H. A. (1970). Chemical composition as a criterion in the classification of aerobic actinomycetes. Int J Syst Bacteriol 20, 435-443.

Lechevalier, M. P., De Bièvre, C. \& Lechevalier, H. A. (1977). Chemotaxonomy of aerobic actinomycetes: phospholipid composition. Biochem Syst Ecol 5, 249-260.

Mikami, H. \& Ishida, Y. (1983). Post-column fluorometric detection of reducing sugar in high-performance liquid chromatography using arginine. Bunseki Kagaku 32, E207-E210.

Minnikin, D. E., O'Donnell, A. G., Goodfellow, M., Alderson, G., Athalye, M., Schaal, A. \& Parlett, J. H. (1984). An integrated procedure for the extraction of bacterial isoprenoid quinones and polar lipids. J Microbiol Methods 2, 233-241.

Nakajima, Y., Kitpreechavanich, V., Suzuki, K. \& Kudo, T. (1999). Microbispora corallina sp. nov., a new species of the genus Microbispora isolated from Thai soil. Int J Syst Bacteriol 49, 1761-1767.

Ørskov, J. (1923). Investigations into the morphology of the ray fungi. Copenhagen: Levin and Munksgaard.

Saitou, N. \& Nei, M. (1987). The neighbor-joining method: a new method for reconstructing phylogenetic trees. Mol Biol Evol 4, 406-425.
Sasser, M. (1990). Identification of bacteria by gas chromatography of cellular fatty acids, MIDI Technical Note 101. Newark, DE: MIDI Inc.

Schleifer, K. H. \& Kandler, O. (1972). Peptidoglycan types of bacterial cell walls and their taxonomic implications. Bacteriol Rev 36, 407-477.

Shirling, E. B. \& Gottlieb, D. (1966). Methods for characterization of Streptomyces species. Int J Syst Bacteriol 16, 313-340.

Stackebrandt, E., Rainey, F. A. \& Ward-Rainey, N. L. (1997). Proposal for a new hierarchic classification system, Actinobacteria classis nov. Int J Syst Bacteriol 47, 479-491.

Staneck, J. L. \& Roberts, G. D. (1974). Simplified approach to identification of aerobic actinomycetes by thin-layer chromatography. Appl Microbiol 28, 226-231.

Tamaoka, J. (1994). Determination of DNA base composition. In Chemical Methods in Prokaryotic Systematics, pp. 463-470. Edited by M. Goodfellow \& A. G. O’Donnell. Chichester: Wiley.

Tamaoka, J. \& Komagata, K. (1984). Determination of DNA base composition by reversed-phase high-performance liquid chromatography. FEMS Microbiol Lett 25, 125-128.

Tamura, T., Hatano, K. \& Suzuki, K. I. (2006). A new genus of the family Micromonosporaceae, Polymorphospora gen. nov., with description of Polymorphospora rubra sp. nov. Int J Syst Evol Microbiol 56, 1959-1964.

Thawai, C., Tanasupawat, S., Itoh, T., Suwanborirux, K. \& Kudo, T. (2004). Micromonospora aurantionigra sp. nov., isolated from a peat swamp forest in Thailand. Actinomycetologica 18, 8-14.

Thompson, J. D., Higgins, D. G. \& Gibson, T. J. (1994). CLUSTAL W: improving the sensitivity of progressive multiple sequence alignment through sequence weighting, position specific gap penalties and weight matrix choice. Nucleic Acids Res 22, 4673-4680.

Thompson, J. D., Gibson, T. J., Plewniak, F., Jeanmougin, F. \& Higgins, D. G. (1997). The CLUSTAL_X windows interface: flexible strategies for multiple sequence alignment aided by quality analysis tools. Nucleic Acids Res 25, 4876-4882.

Uchida, K. \& Aida, K. (1984). An improved method for the glycolate test for simple identification of acyl type of bacterial cell walls. J Gen Appl Microbiol 30, 131-134.

Williams, S. T. \& Cross, T. (1971). Actinomycetes. In Methods in Microbiology, vol. 4, pp. 295-334. Edited by C. Booth. London: Academic Press. 